\title{
Analyzing REDD+ as an experiment of transformative climate governance : Insights from Indonesia
}

\section{Korhonen-Kurki, Kaisa}

2017-07

Korhonen-Kurki , K, Brockhaus , M , Efrian , M , Juhola , S, Moira , M , Cynthia , M \& Bimo , D 2017 , ' Analyzing REDD+ as an experiment of transformative climate governance :

Insights from Indonesia ' , Environmental Science \& Policy , vol. 73 , pp. 61-70 . https://doi.org/10.1016/j.envsci.2017

http://hdl.handle.net/10138/308908

https://doi.org/10.1016/j.envsci.2017.03.014

cc_by_nc_nd

acceptedVersion

Downloaded from Helda, University of Helsinki institutional repository.

This is an electronic reprint of the original article.

This reprint may differ from the original in pagination and typographic detail.

Please cite the original version. 


\title{
Analyzing REDD + as an experiment of transformative climate governance: Insights from Indonesia
}

\author{
Korhonen-Kurki Kaisa ${ }^{\mathrm{a}, \mathrm{b}, *}$, Brockhaus Maria ${ }^{\mathrm{d}}$, Muharrom Efrian ${ }^{\mathrm{b}}$, Juhola Sirkku ${ }^{\mathrm{c}}$, \\ Moeliono Moira ${ }^{\mathrm{b}}$, Maharani Cynthia ${ }^{\mathrm{b}}$, Dwisatrio Bimo ${ }^{\mathrm{b}}$ \\ ${ }^{\text {a }}$ Helsinki University Center for Environment (HENVI), PO.Box 65, 00014, University of Helsinki, Finland \\ ${ }^{\mathrm{b}}$ Center for International Forestry Research (CIFOR), P.O. Box 0113 BOCBD Bogor 16000 Indonesia \\ ${ }^{\mathrm{c}}$ Department of Environmental Sciences, PO. Box 65, 0014, University of Helsinki, Finland and Department of Built Environment, Aalto University, Finland \\ d Department of Forest Sciences, PO. Box 27, 0014, University of Helsinki, Finland
}

\section{A R T I C L E I N F O}

\section{Keywords:}

REDD +

Forest governance

Transformation

Climate change

Indonesia

\begin{abstract}
A B S T R A C T
This paper contributes to an emerging body of literature on policy experimentation and governance transformation processes. We use the example of REDD + as consisting of policy experiments in an emerging domestic policy domain to understand obstacles to transformations in forest and climate governance. We ask two interlinked questions: to what extent did the establishment of the REDD + Agency challenge 'business as usual' in Indonesia's forest and climate policy arena?; and what does this mean for a transformation away from policies and governance that enable deforestation and forest degradation? We draw on the transformation literature to better understand the role of REDD + to achieve a transformative shift in climate governance. As an experiment of transformative climate governance, the study of REDD + provides important insights for other forest or climate programs. Our analysis shows that the REDD + Agency was successful in some extend in introducing an alternative governance mechanism and in shaking the governance structures but we also note that some of the key actors thought that greater ownership was achieved when the REDD + Agency was dissolved and the mandate was returned to the ministries. We conclude that policy experimenting is a process, and while the creation of novel policies and their experimentation is important, also their assimilation may lead to new opportunities.
\end{abstract}

\section{Introduction}

Forests play a vital role in global climate regulation. Deforestation and forest degradation are the largest sources of greenhouse gas emissions in developing countries, and they have accounted for $11-13 \%$ of all global $\mathrm{CO}_{2}$ emissions during the last decade (Friedlingstein et al., 2010; Baccini et al., 2012). In response to this, reduction of emissions from deforestation and forest degradation, and enhancement of forest carbon stocks in developing countries (REDD +) has emerged as a climate change mitigation mechanism.

The importance of forests in climate change mitigation (and adaptation) was reconfirmed in the Paris Agreement, and REDD+ continues to be an important mechanism to achieve climate targets in land-use and forest sectors. REDD + aims to achieve a shift from project-based conservation to more integrated, nationally led policy reforms, including reforms in incentive structures that lead away from deforestation and forest degradation. At the local level, REDD + is implemented via diverse pilot projects (Corbera and Schroeder, 2011;
Sunderlin et al., 2014) that aim to demonstrate avoided deforestation and degradation (e.g. by measuring the carbon stored in trees), as well as promoting various other co-benefits, such as biodiversity protection and improvements in livelihoods for local people.

Research on REDD + has increased during the past nine years (Mbatu, 2016) and includes: experiences on pilot projects (Hajek et al., 2011; Murdiyarso et al., 2011; Peskett et al., 2011); the role of REDD + in international climate negotiations (Reinecke et al., 2014); monitoring, reporting and verification (Korhonen-Kurki et al., 2013; Salvini et al., 2014); and the risks and opportunities it presents on a national level (Corbera and Schroeder, 2011; Gupta, 2012). However, studies on institutional and governance structures are scarce among the REDD+ research, despite the fact that the success of REDD + will depend largely on good governance (and efficient institutions) (Mbatu, 2016). In this context, we propose that examining REDD + as a policy experiment can help to address this gap.

We argue that REDD + has a highly experimental character, expressed in the high diversity of governance approaches and pilots,

\footnotetext{
* Corresponding author at: Helsinki University Center for Environment (HENVI), PO. Box 65, University of Helsinki, 00014, Finland.

E-mail address: kaisa.korhonen@helsinki.fi (K.-K. Kaisa).
} 
as well as in the flexibility for realizing REDD + at country level. Thus, REDD + mechanism can be considered as a new, experimental, governance instrument. REDD + is part of an emerging forest governance that is moving away from state control towards more diverse set of actors and instruments It belongs to a set of wide-ranging policy reforms within and beyond the forestry sector that affect not only a narrow set of regulations, but also a broad range of institutional patterns, and aim to change the behavior of actors across sectors and levels (Brockhaus and Angelsen, 2012).

We study these features of a REDD + policy experiment, using Indonesia as a case study, and through this, provide new insights to REDD + debate. We describe the complex institutional setting, where new policies for REDD + are embedded and distinguish transformative factors and restrictive conditions in the policy arena that influence REDD + . Furthermore, we analyze one particular experimental feature of the REDD +, namely the REDD + Agency in Indonesia, and ask two interlinked questions: to what extent did the establishment of the REDD + Agency challenge 'business as usual' in Indonesia's forest and climate policy arena; and what does this mean for a transformation away from policies and governance that enable deforestation and forest degradation?

First, we theorize transformational change in the context of REDD + and introduce the concept of a policy experiment, and develop our analytical framework. Then, we present the methods and materials used for the Indonesian case study. Next, we look deeper into the Indonesian national policy arena. We examine what kind of policy arrangements have been created for REDD + and analyze how they contribute to transformation. In conclusion, we argue that policy experimenting is a process, and while the creation of novel policies and their experimentation is important, also their assimilation may lead to new opportunities.

\section{Policy experiments: a way toward transformation?}

\subsection{Transformational change and REDD+}

The idea of transformations has emerged to explore how change processes take place in society, how societies are enabled and what obstacles prevent them from taking place change processes (Westley et al., 2011). According to Brown et al. (2013); transformation is generally understood to denote a profound, substantial and irreversible change. Fundamental changes in formal and informal institutions that go beyond incremental technical developments appear to be a common feature in the discussions on transformations. Zeitlin et al. $(2005,450)$ present the notion of 'substantive change', by which they refer not only to formal institutions, such as law, policy and rules, but equally to "broad changes in policy thinking". Similarly, Scoones et al. (2015) analyze the multiple forms of transformation and strategies of change, classifying them as 'shaping and resisting structures', 'reframing knowledge', 'realizing institutions and incentives' and 'mobilizing and networking'.

Policy change is an integral part of the broader transformation process. There are several well-known frameworks to study policy change, such as Advocacy Coalition Framework (ACF) (Sabatier, 2007) and the Institutional Analysis and Development framework (Ostrom, 2011) that address the collective action problem, for example. ACF is based on rational policy analysis that expects that actors can solve collective problems and able to produce rational policy processes (Arts, 2012; Sabatier, 2007). ACF focuses policy outcomes and policy learning as a result of advocacy coalitions, policy brokers and outside events (Arts, 2012; see also Pierson, 1993). Pierson (1993) notes that whilst individuals choose, their choices are influenced by incentive structures, and these structures provide strong inducements that frame their decisions to make particular choices. Institutional policy analysis can be considered as a critique of rationalism. Thus, rational choice and rational design are defined by rules, norms and beliefs, and further as 'institutions' that also affect individual level decision-making (Ostrom,
2011).

In the context of forest governance, we understand transformational change as a shift "in discourse, attitudes, power relations, and deliberate policy and protest action that leads policy formulation and implementation away from business as usual policy approaches that directly or indirectly support deforestation and forest degradation" (Brockhaus and Angelsen, 2012; 16-17). To achieve this, innovative policy development and governance experimentation is required to accelerate change processes. We argue that both institutional structure and actors' activities need to be considered when analyzing the change (Pierson, 1993).

To analyze transformational change in the REDD + policy arena, Brockhaus and Angelsen (2012) propose a political economy framework to study factors enabling or hindering larger policy change related to REDD +. 'Institutional setting' is defined as the formal and informal regulations, rules and norms that are established over time and that are not easily changed or transformed (Scharpf, 2000; Baumgartner et al., 2011). Brockhaus and Angelsen (2012) further present four 'I's (institutional stickiness, interests, ideas and information) as interlinked key determinants for change and resistance in the policy arena. Institutions arise from norms, regulations and institutional arrangements; 'interests' refers to different REDD + actors and their material interests; 'ideas' refers to ideological beliefs; and 'information' refers to knowledge and its use in REDD + processes. Numerous frameworks have been used across scientific disciplines to better analyse what we are calling here institutions, interests, ideas and information. Even though terminology and perspectives vary, they do not differ as much as, for example, when sociologists use concepts of culture, knowledge, power and history. Hall (1997) and Grindle (1999) apply these to the discipline of political economy.

We further see the actors as players in the 'policy arena', which is framed by institutions but shaped by the actions of the actors (whether individuals, communities, organizations or networks) and characterized by more or less hierarchical or inclusive processes, involving a range of powerful actors, which can foster or prevent certain policies and influence policy formulation (see, for example, Corbera and Schroeder, 2011; Arts, 2012). Grin $(2006,63)$ argues that if structures operate through acting agents (actors), the latter are the ones who in principle might be more reflexive. Structure and action may be transformed "though structuration processes guided by deliberate 'reorientation"' - a process that Grin calls 're-structuration' (Grin 2006; 63).

\subsection{Policy experiments in REDD+}

Experiments can bring about a shift in attitudes, power relations and deliberate policy action, and thus contribute to transformation. Conceptually, the initiation of experimental governance represents the development of novel 'rule structures' for participation and learning within an already established pattern of institutional arrangements and actor constellations (Ostrom, 2011). Within policy literature, various definitions of 'experiments' are offered; a common denominator and defining element is a hypothesis driven approach in which variables and elements are intentionally modified in order to systematically generate knowledge (Van den Bosch, 2010).

Experimentation often involves testing, piloting or demonstration and is under continuous assessment and adaptation in response to reallife system conditions (Van den Bosch, 2010). Thus, experiments are usually seen as local trials, or small-scale projects that are closely controlled. In addition, the focus of experimentation is diverse and can also relate to a technology, a practice, a program or a policy. The literature on policy or governance experimentation is traditionally linked to the literature on adaptive management (Holling, 1978; Walters, 1986). In other words, experimentation is triggered by an intentional destabilization of existing institutions and routines, which actors can induce to explore novel possibilities and outcomes of 
informed deliberation. Hoffmann (2011) states that experimentation is recognized for its 'novelty function' outside established policy order.

We consider that REDD+ mechanism as a whole is a part of experimentalist climate governance which contains demonstration sites (pilot projects) but as well several policy experiments, which depart from 'traditional' modes of governance. These experiments have impacted both the institutional structure and the actors involved in REDD + . The experimentation is often invoked under conditions of institutional uncertainty to learn of what would work the best to implement the new type of policy, and this is also a case of REDD + in Indonesia.

In terms of the institutional structure, features of these experiments have included the emergence of collaborative networks, reflecting different ideologies and information. For example, the Governors' Climate and Forests Task Force (GCF) is a unique subnational collaboration between 26 states and provinces from Brazil, Indonesia, Mexico, Nigeria, Peru, Spain and the United States (GCF Task Force, 2014). The task force is an effort to support certain states and provinces around the world that are 'experimenting' to build robust jurisdictional programs for REDD + and low-emissions development, thereby bolstering the overall momentum and enhancing national and international efforts to demonstrate how this can work in practice. Novel bodies have also been created to facilitate horizontal coordination and break ministerial silos, for example in Indonesia, Nepal and Papua New Guinea (Korhonen-Kurki et al., 2015). These bodies cut across the whole national government by including representatives from all of the relevant ministries.

With regards to the actors, there are also examples of various actors becoming involved in REDD + processes, reflecting various interests. This is illustrated by the involvement of nongovernmental organizations (NGOs) in voluntary working groups in various countries in all the stages of REDD + planning. Thus, REDD + has been driven by a growing number of state and non-state actors, creating and filling new structural voids and capacity needs. With REDD + , the roles of intermediaries and third parties in national forest policy implementation seem to grow, provoking changes in governance networks (e.g. the East Kalimantan REDD + working group).

In this paper, we consider the REDD + mechanism including policy experiments that suggests an alternative pathway away from business as usual by challenging the existing regime of forest governance, characterized by deforestation and forest degradation. Thus, policy experiments aim to destabilize the existing regime, introduce change to existing practices and provide alternative sustainability pathways toward transformational change. In particular, we chose one policy experiment, namely, REDD + Agency as an example of policy experiments (see Fig. 1) that may destabilize the existing governance mechanisms in Indonesia and apply this framework to a case study of Indonesian forest governance.

\section{Methods and material}

This study is part of the Global Comparative Study on REDD+ (GCS-REDD), underway in 15 REDD + countries. A policy network analysis was initially conducted in 6 countries (2011-2012) and repeated in 4 countries (Vietnam, Cameroon, Brazil and Indonesia) in 2015-2016. The empirical evidence for this paper is drawn from our case study work in Indonesia, a country which was early on engaged in REDD + and had moved beyond a more technically oriented readiness phase into a phase of policy and institutional change. As pointed out in Brockhaus et al. (2016), a number of REDD + countries have entered this phase and progress as well as struggle with larger change is observed among some of them, for example Indonesia, Brazil and Vietnam. Indonesia was selected as a case study country because since 2009, we have been able to document, first, the establishment of the REDD + agency outside the bureaucratic forestry establishment, then, the surrounding power struggles, and finally, the ongoing assimilation back into the existing forest hierarchies. This development provided an exemplary case of larger change process coming from the Indonesian forest governance system. In addition, Indonesia has one of the highest mitigation potentials through avoided deforestation and we can provide useful lessons for other countries by understanding how policy experiments unfold, enable or hamper a shift away from business as usual in deforestation.

The study employs a mixed method approach, which focuses on research questions that call for real-life contextual understandings and multi-level perspectives, and utilizes multiple methods intentionally integrating or combining them to draw on the strengths of each (see Denscombe, 2008). In qualitative research, it is suggested to use triangulation in order to obtain more valid results. This means developing a more effective method to capture social phenomena, which leads to a more accurate and valid analysis (Creswell and Plano Clark, 2007). Empirical material for the here presented paper is drawn from various sources: (i) key policy documents (Indonesian national REDD + strategy, Task Force documents); (ii) policy event positioning based on a policy network survey conducted in 2012 and repeated in 2015; (iii) key REDD + actor interviews; and (iv) participatory observation of Indonesian REDD + development by the authors, building on a background study of REDD + development in Indonesia (Indrarto et al., 2012).

First, main key policy documents, namely Indonesia REDD + Strategy (2012) and the Readiness Preparation Proposals (R-PP) (FCPF, 2009), were selected for analysis as they are the guidelines for the REDD + implementation and preparation, also guiding the policy making. The documents were reviewed and coded inductively in order to identify transformational and restrictive factors by means of qualitative content analysis (See also Kiema, 2014). Qualitative content analysis aims to explain, clarify and structure the material by means of coding and categorizing in order to provide understanding of the phenomenon under study" (Downe-Wamboldt, 1992). The coding process included analysis of the links between different codes and creating code networks, which were used as a basis for categorization.

Second, the policy network analysis comprised a standardized social organization survey and in-depth interviews with actors (both questionnaires are published in Brockhaus et al., 2014a). The survey tried to capture organizational views concerning issues related to REDD + . Data was collected in Indonesia in 2012 and 2015, to compare possible changes in organizational stances and networks related to REDD + . We interviewed 64 actors in 2012, and 116 actors in 2015 (see Table 1) covering a wide range of actor groups, such as government agencies, national research institutes, national business organizations, private sector such as domestic and international business actors and roundtables, domestic environmental (E) non-governmental organsiations (NGO)s, international (environmental) NGOs and networks, international organizations such as intergovernmental organizations (IGO), international research institutes, transnational organizations of local governments, foreign government agencies, and donors (such as BMZ/ GIZ) and others. The interviews took up to three hours, and interviewers worked mostly in pairs. Interviews were recorded and transcribed.

Actors were selected if the organization defines itself and is perceived by others as a part of the national policy domain. The increase in numbers of relevant actors from phase 1 to phase 2 reflects the growth of the still relatively young domain itself over time, as observed also in Brockhaus et al. (2014a). In addition to the actors, we also identified a number of policy events (see Table 2). A Policy Event is considered in the context of this research "a critical, temporally located decision point in a collective decision-making sequence that must occur in order for a policy option to be finally selected" (Laumann and Knoke, 1987:251). Both, the actor list and the event list were verified by an external committee composed of all different actor categories, to ensure that no actors or key events were missed, nor irrelevant.

The collected interview data was used to identify and explore actors' 


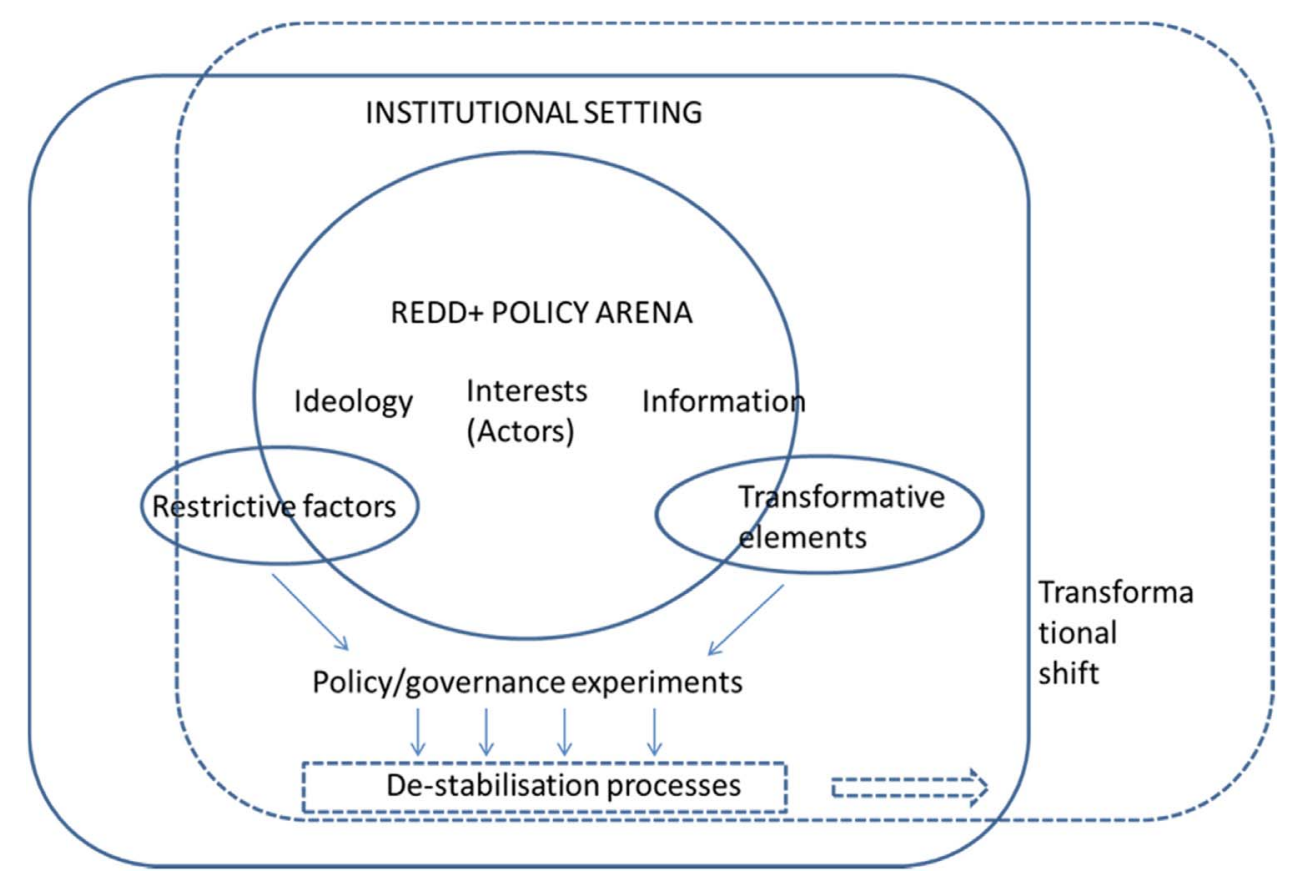

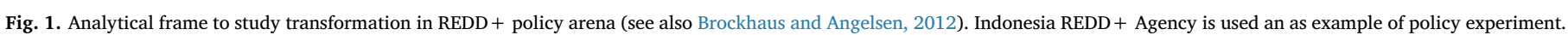

stances toward policies and policy events related to REDD +. Actors were, for example, asked to indicate whether they supported or worked against a particular decision. This included, for example, the establishment of a REDD + agency, or the dissolving of the same later in time. Coordinates of events were attributed based on the extent to which they represented sovereignty concerns versus an interest in an internationalization of REDD +, and to which extent they implied a withdrawing into the well-known bureaucracy versus opening up to other forms of governance. Depending on actors and actor groups' relation to these particular events regarding support or opposition, there position within these two axis was calculated. This analysis enabled us to visualize the interests of particular actor groups had in larger reform efforts. In this process, we controlled for different actor group sizes by normalizing the data.

Third, we used a basic data collection sheet to structure observations around issues such as: key messages provided, major issues that emerged during such meetings or interviews, and interaction among participants (including for example conflicting statements by different participants) to analyse the findings from participatory observation in different policy events. These included e.g. "Stakeholder analysis to enhance smallholder benefit sharing from REDD in Indonesia", organized by Center for Research and Policy of Ministry of Forestry (shortly before it was merged with Ministry of Environment), at October 21,
2014 and "REDD + implementation and its preparation for Paris 2015", organized by Ministry of Environment and Forestry, May 19-20, 2015), and informal interviews since 2009.

Our mixed method approach strengthens the validity of the research as it allows for triangulation of the findings. While we undertook quality control and other measures, such as interviewing in pairs to tackle some of the validity threats (Maxwell, 1992), it has to be noted that not all identified actors could be interviewed. On the other hand, the most influential actors (based on a reputational power analysis as specified in Brockhaus et al., 2014b) within the policy arena have been captured in both moments of time.

\section{Insights from Indonesia: REDD + as transformative climate governance?}

\subsection{REDD + policies embedded in a complex institutional setting}

Since the early years of REDD + development in Indonesia, REDD + was used to act as a catalyst to improve many aspects of governance. In their analysis of enabling conditions for establishing REDD+, Korhonen-Kurki et al. (2014) concluded that a crucial factor was previously initiated policy addressing climate change and aimed at departing from business as usual, developed independently of REDD +.

Table 1

Actors identified and interviewed in phase 1 and phase 2 of the research.

\begin{tabular}{|c|c|c|c|c|c|c|}
\hline \multirow[t]{2}{*}{ Actor Groups } & \multicolumn{3}{|l|}{ Phase 1} & \multicolumn{3}{|l|}{ Phase 2} \\
\hline & $\begin{array}{l}\text { Selected as } \\
\text { respondents }\end{array}$ & Interviewed & $\begin{array}{l}\text { Participated fully in network } \\
\text { survey }\end{array}$ & $\begin{array}{l}\text { Selected as } \\
\text { respondents }\end{array}$ & Interviewed & $\begin{array}{l}\text { Participated fully in network } \\
\text { survey }\end{array}$ \\
\hline Government & 26 & 20 & 19 & 54 & 46 & 46 \\
\hline $\begin{array}{l}\text { University/National Research } \\
\text { Centers }\end{array}$ & 4 & 2 & 2 & 9 & 4 & 4 \\
\hline Private sector & 15 & 11 & 9 & 28 & 22 & 22 \\
\hline $\begin{array}{l}\text { National NGOs (including Local } \\
\text { E \& NGO) }\end{array}$ & 15 & 13 & 13 & 19 & 15 & 15 \\
\hline International NGOs & 10 & 10 & 10 & 14 & 13 & 13 \\
\hline International Organizations/IGO & 5 & 4 & 3 & 6 & 5 & 5 \\
\hline Donor & 8 & 8 & 8 & 16 & 11 & 11 \\
\hline Total & 83 & 68 & 64 & 146 & 116 & 116 \\
\hline
\end{tabular}


Table 2

Key policy events identified for each research phase.

(a) Events selected in phase 1

\begin{tabular}{|c|c|c|c|}
\hline Event code no. & Event name & Proposal/Decision Date & Main decision/policy proposal \\
\hline 1 & COP 13 in Bali & December 2007 & $\begin{array}{l}\text { - Bali Action Map } \\
\text { - Bali Road Map }\end{array}$ \\
\hline 2 & Establishment of DNPI & July 2008 & Presidential Regulation No. 46 \\
\hline 3 & Series of processes related to policy formation on REDD & & $\begin{array}{l}\text { - Permenhut No. 68, } 2008 \\
\text { - Permenhut No. } 30,2009 \\
\text { - SK Menhut No. 21, } 2009 \\
\text { - SK Menhut No. } 64,2010\end{array}$ \\
\hline 4 & G20 Forum in Pittsburgh, US & September 2009 & Komitmen Indonesia mengenai target emisi $26 \%$ \\
\hline 5 & $\begin{array}{l}\text { Signing of Letter of Intent (LoI) between GoI and Norwegian } \\
\text { Government }\end{array}$ & May 2010 & $\begin{array}{l}\text { - Moratorium of peat land and prime forests } \\
\text { - Kepres No. 19, } 2010 \text { on Satuan tugas pesiapan pembentukan } \\
\text { kelembagaan REDD } \\
\text { - Stranas REDD }\end{array}$ \\
\hline
\end{tabular}

(b) Events selected in phase 2

\begin{tabular}{|c|c|c|c|}
\hline $\begin{array}{l}\text { Event code } \\
\text { no. }\end{array}$ & Event name & $\begin{array}{l}\text { Proposal/Decision } \\
\text { Date }\end{array}$ & Main decision/policy proposal \\
\hline 1 & Moratorium & May, 20th 2011 & $\begin{array}{l}\text { - Instruksi Presiden No.10/2011 } \\
\text { - Kepmenhut No. Sk.323/Menhut-II/2011, penetapan PIPIB } \\
\text { - Instruksi Presiden No.6/2013 }\end{array}$ \\
\hline 2 & One Map Policy & $\begin{array}{l}\text { December 23rd, } \\
2010\end{array}$ & • Participative map standardization by BIG \\
\hline 3 & REDD + National Strategy & $\begin{array}{l}\text { September 19th, } \\
2012\end{array}$ & - SK Ketua Satgas REDD + No. 02/SATGAS REDD PLUS/09/2012 \\
\hline 4 & $\begin{array}{l}\text { Constitutional Court Decision No. 35/2012 } \\
\text { about Adat Forest }\end{array}$ & March 26th, 2013 & $\begin{array}{ll}\bullet & \text { MK no.35/PUU-X/2012 } \\
\text { - } & \text { SK.3201/Menhut-II/Kum/2013 } \\
\text { - SK.167/II-Kum/2013 } \\
\text { - SE.1/Menhut-II/2013 } \\
\text { - } \text { Permendagri No.52/2014 }\end{array}$ \\
\hline 5 & REDD + agency establishment & $\begin{array}{l}\text { September 2nd, } \\
2013\end{array}$ & • Perpres No.6/2013 \\
\hline 6 & $\begin{array}{l}\text { Presidential decree No. } 16 / 2015 \text { about } \\
\text { Ministry of Environment and Forestry }\end{array}$ & January 21st, 2015 & $\begin{array}{l}\text { National Council of Climate Change (DNPI) and REDD + agency (BP REDD +) tasks } \\
\text { merged into Ministry of Environment and Forestry (disolvement of DNPI and BP REDD +) }\end{array}$ \\
\hline
\end{tabular}

This includes, Nationally Appropriate Mitigation Actions (NAMA), antideforestation programs, low-carbon development strategies and payment for environmental services schemes, which are all present in Indonesia. In addition, the establishment of the anti-corruption agency can be considered a previously initiated governance reform. Further enabling policies include, other climate and environmental policies and reform attempts, and tenure and forestry reforms that facilitate the implementation of REDD + .

However, the Indonesian institutional setting also features several constraining factors, including: tax breaks and other incentives that stimulate deforestation and forest degradation, regulations that conflict with conservation aims, and poor implementation of pro-REDD + reform. Fig. 2 illustrates the complex institutional setting for REDD +. To sum up, at the same time there are policies that are specific for REDD + (in the middle Fig. 2) or hinder (left in Fig. 2) or enable (right in Fig. 2) the establishment of REDD +.

\subsection{Overview of the REDD + policy arena: transformative factors and restrictive conditions}

In addition to institutional setting, we identified some of the important transformative factors and restrictive conditions for REDD + in the Indonesian policy arena (see Table 3)

There are several interests, both material and non-material that drive REDD + (see Korhonen-Kurki et al. (2014) and Brockhaus et al. (2016) for a detailed list of enabling factors for establishing REDD +). A clear manifestation of the interests that drive away from business as usual is the political will that clearly supported effective, efficient and equitable REDD + policies at the highest level of government. This was indeed the case in Indonesia during the presidency of Susilo Bambang
Yudhoyono (2004-2014), in which most of the REDD + policy design was implemented.

Internationally and domestically, President Susilo Bambang Yudhoyono aimed to show leadership on combating climate change. This was demonstrated through the pledge made at the G20 Pittsburgh Summit and repeated at the Copenhagen Climate Change Conference, to independently reduce greenhouse gas emissions by $26 \%$ from business as usual by 2020 , and by $41 \%$ with assistance from other countries; although many parties questioned the emission baseline used for this pledge. The pledge was used by the Ministry of Environment to formulate the Greenhouse Gases National Action Plan (RAN-GRK), and as a reference for other ministries to reduce greenhouse gas emissions from their sectors. The next government also used the pledge as a guideline for low-carbon development in its National Midterm Development Plan (RPJMN). There were also clear notions of coalition building by the actors that share the same interests in moving away from business as usual (participant observation).

Regarding material interests, several economic incentives for avoided deforestation and forest degradation have been introduced. FREDDI the funding instrument for REDD + in Indonesia, was designed to attract private and public investments for REDD + in order to provide a new type of funding that could treble the existing funding structures (Ardiansyah et al., 2015).

These developments have been complimented by some promising action on deforestation in the private sector, with zero-deforestation pledges made by several large oil palm producers. However, the effectiveness of these pledges is challenged by many, as the role of smallholder producers is not taken into account, and implementation would endanger their livelihoods in favor of big producers. Implementation may be challenging on the ground, but there is a clear 


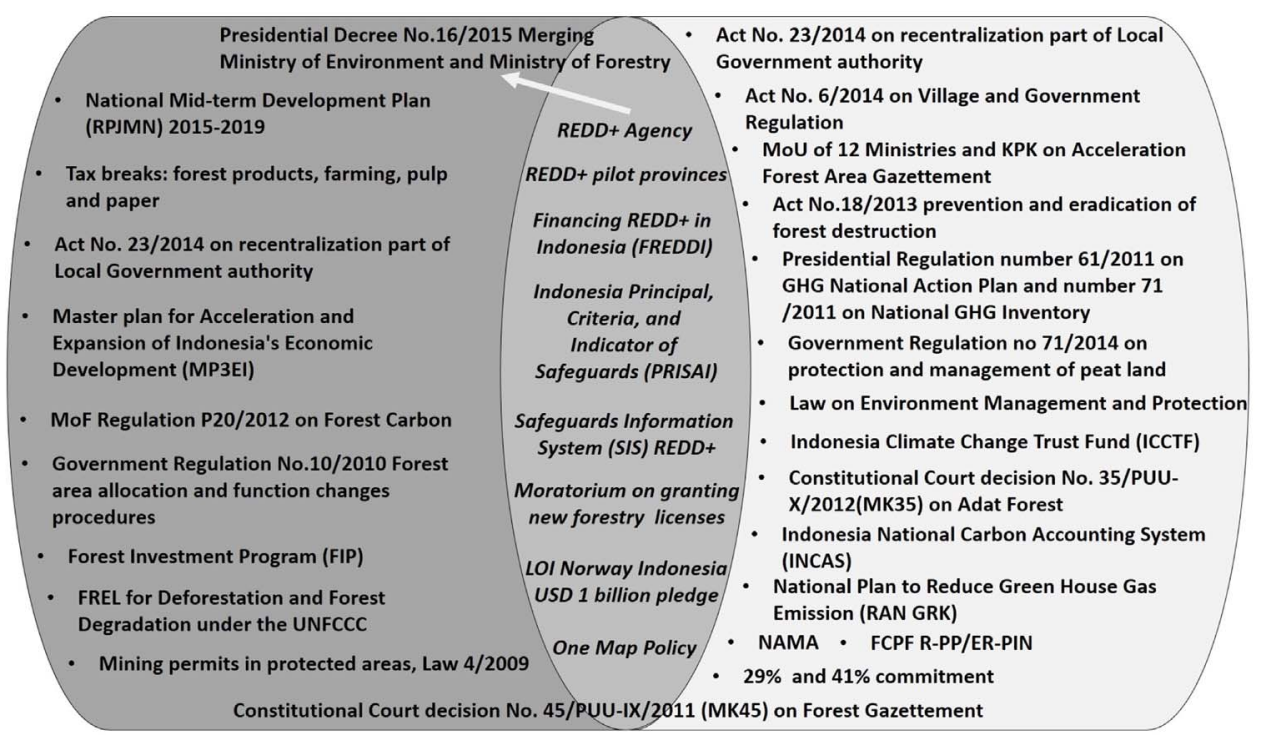

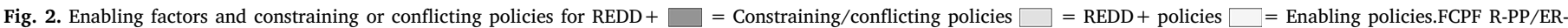

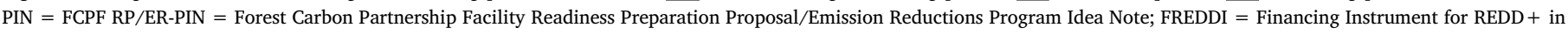

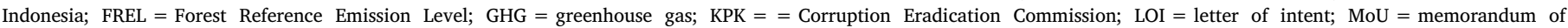
understanding; NAMA = Nationally Appropriate Mitigation Actions; UNFCCC $=$ United Nations Framework Convention on Climate Change.

shift in the private sector toward seeking climate friendly solutions, and REDD + discourse has contributed to this development in Indonesia.

In terms of civil society action, various working groups and platforms for participation have been established, which have been reconfiguring existing governance networks and creating new opportunities for participation. Even though REDD + has been criticized as a top-down process, the new civil society platforms have created novel channels for civil participation.

In terms of ideas and ideologies that shape the politics of forest and climate governance, there have been signs of a paradigm shift toward a more pro-climate regime in Indonesia. The REDD + National Strategy, which has introduced a new vocabulary to change the working culture of forest governance at all levels, can be seen as a sign of this. The strategy has introduced the following principles that need to be addressed in changing the paradigms and culture of forest governance: gender sensitivity, inclusiveness, collaboration, adaptability and transparency. In addition, in strengthening forest and land-use governance, the strategy envisioned the leveraging of the Public Information Disclosure $14 / 2008$ to ensure transparency and the availability of information for public participation (see Indonesian REDD + Task Force 2012). Also, a special 'Green Bench' of judges has been formed to adjudicate on environmental cases, including forestry issues. Integrity and 'sufficient' knowledge of sustainable development, including its application in the forestry sector, are the main selection criteria in determining its members.

Finally, reporting of carbon and co-benefits for REDD+ has increased the amount of accessible information, even though not all data, in particular with regard to concessions, are actually available, despite initiatives such as the Public Information Disclosure.

In contrast to several promising transformative factors, other factors in the policy arena restrict REDD + implementation. REDD + has suffered from limited support in the national budget and has relied mostly on international donors during what is supposed to be a 'transition' period to the establishment of carbon markets.

Furthermore, various cross-sectoral challenges continue to exacerbate the conflict between the goals of avoided deforestation and business-as-usual investment. There has also been an alignment problem with other policy sectors (see more in Korhonen-Kurki et al., 2015; Di Gregorio et al., 2017). In addition to this, earlier, rather radical changes - such as the establishment of the REDD + Task Force by presidential decree, outside of the structure of government bureaucracy - faced resistance and conflict, as we describe in the next section.

\subsection{The REDD + agency as a key feature in Indonesian's REDD + policy experiment}

In 2010, Norway and Indonesia signed a letter of intent in relation to a 1 billion USD pledge based on performance. As a result, the REDD + Task Force was established as a preliminary institution with overall responsibility for REDD + . It comprised a chair, a secretary and nine members representing the Ministry of National Development Planning (BAPPENAS), the Ministry of Forestry, the Ministry of Finance, the State

Table 3

Summary of transformative factors and restrictive conditions.

\begin{tabular}{|c|c|c|}
\hline & Transformative factors & Restrictive conditions \\
\hline Interests & $\begin{array}{l}\text { - Political will (during previous presidency) } \\
\text { - Transformational coalitions } \\
\text { - Incentives for avoided deforestation and forest degradation (donor push) } \\
\text { - Promising developments in private sector on no-deforestation policy }\end{array}$ & $\begin{array}{l}\text { - Limited budget support } \\
\text { - No recognition of REDD + by other policy sectors }\end{array}$ \\
\hline Ideas/ideologies & - Signs of paradigm shift toward pro-climate regime & - Conflicting development and investment goals \\
\hline Institutions & $\begin{array}{l}\text { - Novel and alternative governance mechanisms } \\
\text { - Novel public-private partnerships } \\
\text { - Novel funding via FREDDI }\end{array}$ & $\begin{array}{l}\text { - New mechanisms have no legal power } \\
\text { - Nature of coalition politics in Indonesia } \\
\text { - Delays in global carbon markets } \\
\text { - Lack of multilevel and multisectoral governance }\end{array}$ \\
\hline Information & - Reporting on carbon & - Inadequate information flow \\
\hline
\end{tabular}

a See Luttrell et al., 2014. 
Ministry for Environment, the National Land Agency, the secretariats of the Cabinet and Presidential Office, and the President's Delivery Unit for Development Monitoring and Oversight (UKP4). The term of the task force was extended twice. Kuntoro Mangkusubroto used his strategic position as head of the REDD + Task Force based in the Office of the President to push a number of important reforms, including the forest licensing moratorium and disclosure of forestrelated data. However, his ability to move forward was checked by resistance from the powerful Ministry of Forestry, which viewed the establishment of the REDD + Agency in 2014 as a threat (Brockhaus and Di Gregorio, 2014; Seymour, 2012).

The REDD + Agency replaced the REDD + Task Force in 2014. It was established as a ministerial-level institution, and was run by a director, four deputies and a staff of 60 professionals. Essentially, the task force was renamed and restructured, with the resources remaining more or less the same.

The agency supported the president in implementing the tasks of coordination, synchronization, planning, facilitation, management, monitoring and control of REDD + in Indonesia. It aimed to harmonize REDD + with other policies. The REDD + Agency was independent of the traditional government structure. The new agency was used as an opportunity to push reforms to break the task silos of ministries (Observation from presidential decree, see also Indrarto et al., 2012)

However, despite the novel governance arrangements developed for REDD +, the change in political leadership in 2014 turned the institutional landscape around. After governing Indonesia for two periods, and showing strong a commitment to fighting climate change, particularly through REDD +, Susilo Bambang Yudhoyono was replaced as president by Joko Widodo. The current president, with a civilian and business background, has raised expectations for a transparent, effective and efficient government, all of which would be central to major changes in the forestry sector (Mission and Vision statements: "Nawa Cita", 9 Agenda Prioritas Jokowi-JK).

In early 2015, Widodo rearranged many of the ministries, in terms of their nomenclatures and tasks. The most significant rearrangement in relation to climate change policy development was the merger between the previously separate Ministry of Environment and Ministry of Forestry (MoF). This was followed by the dismissal of independent institutions that had been established as part of the climate change regime in Indonesia: the National Climate Change Council (DNPI) and REDD + Agency. The absorption of their tasks by the Ministry of Environment and Forestry (MoEF) was made through the issuance of Presidential Decree No. 16/2015. (Presidential Decree no 16/2015 on the Ministry on Environment and Forestry)

Before formally determining the structure of the merged ministries, the MoEF itself issued the Minister of Environment and Forestry Regulation on Licensing and Non Licensing Authority Delegation to Investment Coordination Board (BKPM). This policy was instituted to support the One Stop Services on Investment, which is key to the government's agenda to improve the investment climate in the country and to ease investment licensing processes. It is important to note the potentially contradictory characteristics of these two institutions: the BKPM aims to attract as much investment as possible to the country, while one of the main tasks of the MoEF is conservation and protection of the environment. Many have questioned the effectiveness of the policy of conserving forests while accelerating investment processes. The time line of REDD + institutional evolution is illustrated in Fig. 3.

The merger itself was not painless and has been described as a 'forced marriage' between two unequal partners (Interview with domestic environmental NGO). The Ministry of Environment although having the mandate to monitor the environmental impact of all agencies, was a small organization (with only about 5000 staff) and had become insignificant compared to its early years under the former minister, Emil Salim. The MoF, on the other hand, has always been a powerful agency by virtue of controlling a large proportion of Indonesia's territory, and has around 21,000 staff. Some informants pointed out that it is difficult for the old foresters in this bureaucracy to cede their 'exclusive status' and be integrated into a new institution. As one respondent from civil society stated: "having been in power for so long they cannot easily change clothes". The new minister is open to change, but the bureaucracy is resistant. Some actors, particularly from civil society, are therefore concerned that environmental issues will be overshadowed by the forestry portfolio. Thus far, the environment and forestry portfolios are segregated into different directorate generals and operate in parallel rather than being integrated.

By integrating the REDD + mandate into the MoEF, REDD + was 'returned' to the purview of a bureaucratic institution. However, national civil society actors also expressed their hope that as part of the bureaucracy, coordination would be more effective and the national sense of ownership might be strengthened.

Some critics of merging the REDD + Agency into the MoEF say that without first completing the reform of the forestry and environmental sectors, it will be impossible to operate REDD + from within the MoEF. (Interviews of environmental justice NGO, customary rights based NGO). The respondents believe that it would have been better to maintain an independent REDD + agency, although with a clearly circumscribed mandate and time limit, in order to build the capacity of all relevant ministries and actors to implement REDD + according to their mandates. This was the view of many international organizations. However, other respondents, particularly from domestic organizations, said that the REDD + Agency was not effective anyway, as it did not have the authority to decide on use and allocation of forest areas. Indeed, one of the consistent criticisms of the REDD + Agency (and of the DNPI) was that it was outside the bureaucracy, without authority for implementation and thus not listened to.

The whole climate change agenda in Indonesia is thus managed by the MoEF, and covers adaptation; mitigation; inventory of greenhouse gas emissions; monitoring, reporting and verification; as well as regional resource mobilization and forest fire control. Interestingly, to support the Directorate General for Climate Change(DG PPI) in this task, and protect institutional independence and objectivity, an advisory council was formed headed by a former minister for the environment, with members including NGO representatives and senior bureaucrats, supported by foreign technical cooperation. ${ }^{1}$ Within the current structure of the MoEF, REDD + tasks are assigned to a sub-directorate of the DG PPI; as a small part of the overall MoEF operations, there are concerns that it might lose visibility. On the other hand, as one respondent said, the DG PPI is not the implementer but should coordinate REDD + policy across different ministries/government agencies and other stakeholders. Implementation should be mainstreamed and integrated throughout the directorates and sub-directorates of all government agencies.

As a sub-directorate within the MoEF, the capability of the DG PPI to coordinate other stakeholders is also in question, especially other ministries. While some criticism of the REDD + Agency related to its position outside the bureaucracy, its special position also allowed it to bring stakeholders together, although only further process could tell whether its coordination could have extended to implementation. The existence of the REDD + agency (BP REDD + ) also neutralized competition between the MoF and BAPPENAS for control of REDD+. This competition might now play out between the DG PPI, advisory council and the special envoy on directing climate change policy - even though the director of DG PPI is the official focal point for the United Nations Framework Convention on Climate Change (UNFCCC). It remains to be seen whether the MoEF absorption of the REDD + Agency means greater national ownership as some respondents assume, or it leads to

\footnotetext{
${ }^{1}$ Presidentail Decree 16/2015, through issuance of Minister of Environment and Forestry Regulation NO.: P. 18/MENLHK-II/2015, on MoEF organization and working procedure Presidentail Decree 16/2015, through issuance of Minister of Environment and Forestry Regulation NO.: P. 18/MENLHK-II/2015, on MoEF organization and working procedure.
} 


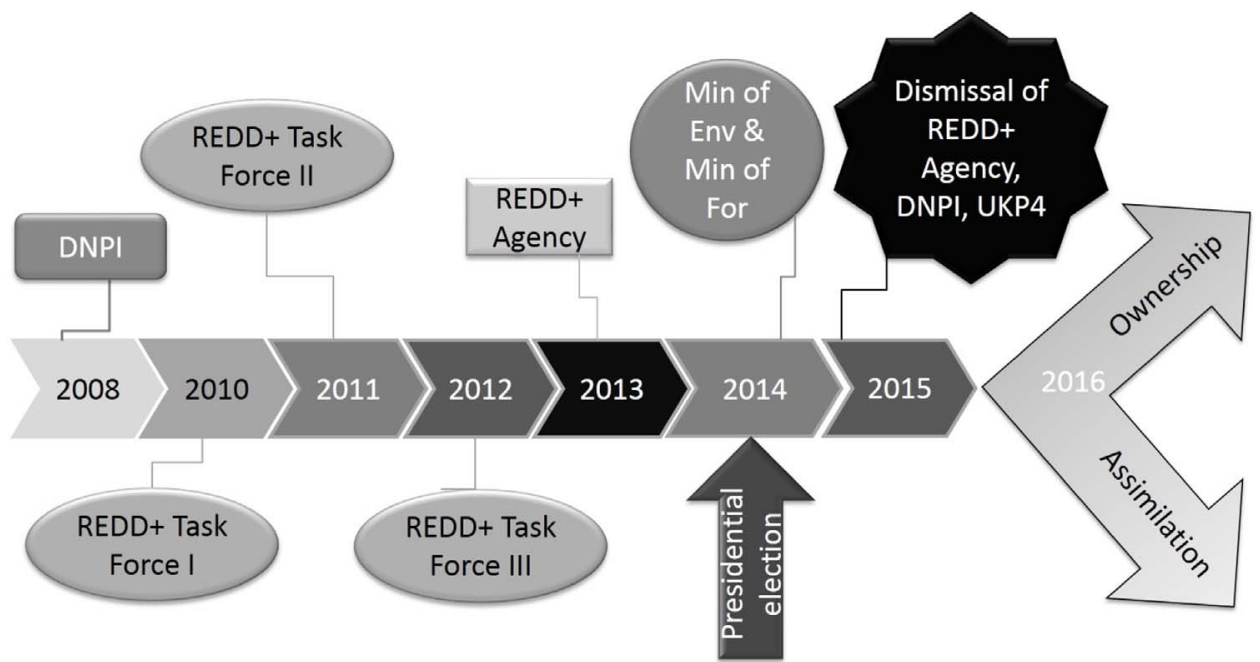

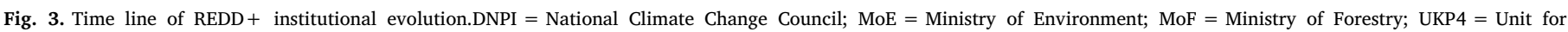
Developing Monitoring and Oversight.

assimilation of REDD + into other activities, such that no transformational aspects remain (see Fig. 3).

Over time, a long list of REDD + policy events has taken place, including the signing of the letter of intent and the formation and dissolution of bodies, such as the DNPI and the REDD + Agency (see Fig. 3). However, not all of these policy events were supported by all actor groups within the REDD + policy arena. We found major differences in the extent to which actor groups supported or opposed REDD + policy events. Taking a closer look at these events, they reflect to different extents some key experimental characteristics of policymaking, with regard to institutional structure (away from hierarchy and bureaucracy within the country) and more openness (and engagement) toward international processes.

We organized the different policy events along two continuums (Fig. 4): sovereignty concerns versus internationalization of REDD + (x- axis); and withdrawing into versus opening the bureaucracy (y-axis). We found, perhaps unsurprisingly, that intergovernmental organizations and international research organizations within the REDD + arena mostly support less bureaucracy and more internationalization of REDD + . In contrast to this is the government actor group, which is very concerned over sovereignty issues and supports a re-bureaucratization of REDD +. Interesting perhaps is the positioning of business actors (domestic and international) and national research organizations, which show quite similar patterns of support. One could argue that those actors that supported maintaining an independent REDD+ agency demonstrate more transformational intentions, as this policy is aiming at an institutional set up that would open up the bureaucracy and would move beyond inward-oriented national concerns. The diagonal from the bottom-left quadrant to the top-right quadrant could then reflect more transformational potential. However, as we will argue

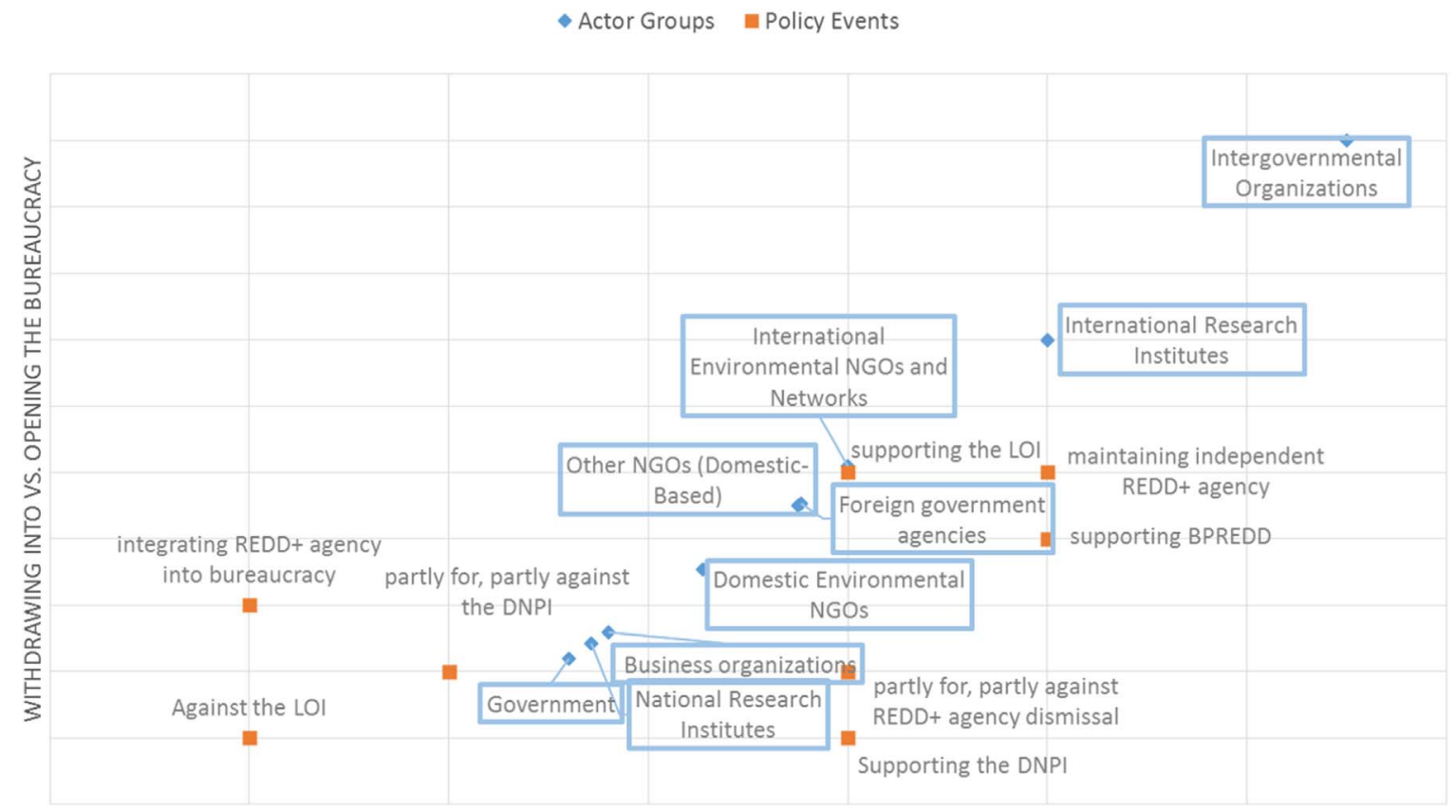

SOVEREIGNTY CONCERNS VERSUS INTERNATIONALISATION OF REDD+

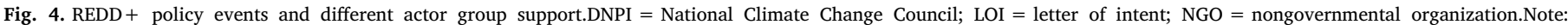

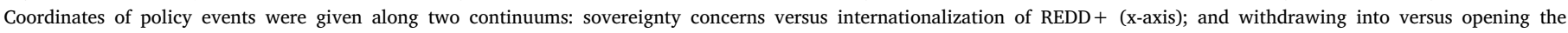

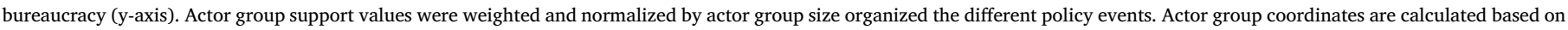
the support values for the different policy events. 
in the next section, the most recent policy event, the establishment of the directorate Jenderal Perubahan Iklim within the newly created MoEF, is much debated by a variety of stakeholders. Some see it as a step toward realizing change for REDD + , while others consider the abolishment of the agency a step backward for REDD + establishment in Indonesia.

In general, it seems that climate change and REDD + have become less significant topics for the government of Indonesia and are considered less important in contributing to development efforts (Cronin et al., 2016). The Midterm Development Plan for 2015-2019, which is the basic reference document for every sector in the country, does include a statement on the commitment to independently reduce greenhouse gas emissions by $26 \%$ by 2020 (and by $41 \%$ with support from foreign countries) but REDD + is not mentioned at all. The emphasis is clearly on development with no explicit mentioning of environmental or climate change issues and the potential economic incentives associated with REDD + . The abolishing of the REDD + Agency and the DNPI is taken by some informants as a signal that the government is not interested in these issues anymore.

\section{Conclusions: lessons learned from REDD + policy experiment experience}

REDD + was welcomed by the Government of Indonesia during its early inception, following the adoption of the Bali Road Map in 2007. A policy initiative started, with demonstration sites on the ground and numerous institutional and regulatory changes. A REDD + Agency was created outside the established forestry ministry bureaucracy with highlevel political support to overcome the difficulties of sectorial power battles and increase the visibility and effectiveness of the climate agenda. However, this agency was later dissolved due to a change in political leadership.

As mentioned above, a number of restrictive factors and transformative elements affect the ability of an experiment to destabilize fully an existing institutional setting. Based on our analysis, we conclude that the REDD + Agency was successful in some extend in introducing an alternative governance mechanism that formed a bridge between ministerial silos, solving sectoral difficulties. However, we note that some of the key actors thought that greater ownership was achieved when the REDD + Agency was dissolved and the mandate was returned to the ministries. Hence, the perhaps more relevant question is what enabled the system after the REDD + agency stir-up to bounce more or less back into established hierarchies of bureaucracy, and a business as usual in terms of decision making over standing forests.

Institutional stickiness, namely that the most powerful organizations are typically those that resisting change most strongly, is one possible explanation. The experimental lens in our case confirms this, seeing that the governmental actor group mainly has the tendency to be concerned over sovereignty and supporting a bureaucratization of REDD + . We argue in this article that considering the rise and metamorphosis of the REDD + agency as a policy experiment could provide useful insights into dynamics of transformational change, which would be required to move away from business as usual of deforestation. In addition, the policy experiment of the REDD + Agency in Indonesia was based on specific ideologies of monetary incentives to support avoided deforestation (represented in the 4I framework by ideas and interests). It thus reflects the interests of those actors who support the market mechanism as a vehicle for change in the climate arena. Those actors included in the first phase, the highest political powers such as the President, as well as private and international organizations. However, when the political landscape changed, the more traditional interest of economic development through traditional production models overcame the climate interest and this was also shown in practical governance arrangements. In other words, REDD + is now returned to the ministry, which led perhaps a greater sense of ownership over the REDD+ idea, but perhaps also to an implicit rejection of the REDD + objective, mainly the avoidance of deforestation and forest degradation. Hence, it remains to be seen whether this process of assimilation will result in efficient forest and climate policies or support business and usual development.

The policy experiment lens allowed us to unpack for the case of Indonesia a number of 'revolutionary' aspects (e.g. the earlier institutional configuration, newly emerging ideas representing new discourses and ambitions with regard to climate change and forests role within) that all contributed to a reshuffling of existing power relations and institutional structures, all of which were promising in terms of larger transformations as literature suggests. However, our findings show that this 'shacking up' was most probably not sufficient to establish and pursue the intended reform agenda, as deforestation, even though very much discussed, still continues in Indonesia at a steep pace.

While all these dynamics are highly case-specific to Indonesia, e.g. the change in leadership and the reconfiguration of interests with regard to forests, there are a number of insights that can be gained for the analysis of reform processes in other countries as well, as for example in Brazil the earlier (and rather successful) command-and control experiment combined with a remote sensing revolution to tackle deforestation seems now to be taken a different shape, and the policy framework is seemingly changing in favor of business as usual interests. However, more systematic case studies of policy experiments would be necessary to analyse to which extent an experiment could trigger change with regard to particular policy objectives, but much more importantly to understand what aspects, enabling or hampering, within a particular experiment are shared across diverse cases.

Non-surprisingly, our case study showed that policy experiments and innovations are not linear. They may include various phases from creation to dissolution and reintegration, and end in reforms that had not be planned in the beginning. We also argue that the assimilation processes may give space for re-alignment of governance. That is to say that policy experiment is not the end in itself, but a start. Policy experimenting is a process, and while the creation of novel policies and their experimentation is important, their assimilation may lead to new opportunities. Moving the process forward is what matters.

Our analysis shows the emergence and the downfall of the REDD+ Agency as a policy experiment provided useful insights into the overall REDD + debate and reflects the overall struggles REDD + is facing as a mechanism to reduce deforestation in Indonesia. Our analysis demonstrated that when studying a highly complex policy arena, an experimental view is useful to understand the diversity of interests of actors, but more importantly it allows for taking into account over a longer time period the changing political landscape and institutional structures where transformation needs to happen - and it might help to identify obstacles and opportunities for change that themselves are not stable and fixed, but also change over time.

\section{Acknowledgements}

The research presented in this paper forms part of the CIFOR-led Global Comparative Study on REDD + (GCS REDD +) and funding for this work was provided by the Norwegian Agency for Development Cooperation (Grant No. QZA 12/0882). We are very grateful to all interviewees for their willingness to share their insights and knowledge with us. Without their input this research would not have been possible. We would also like to thank John Sonnett and Caleb Gallemore for their input on the 2-mode network analysis. Thanks also to the organizers of and participants in the INNOGOV COST workshop in Helsinki March 2015, which provided the impetus to write this paper, and special thanks to the reviewers whose comments helped to improve the manuscript.

\section{References}

Ardiansyah, F., Marthen, A.A., Amalia, N., 2015. Forest and Land-use Governance in a Decentralized Indonesia: A Legal and Policy Review. Occasional Paper 132. Center 
for International Forestry Research, Bogor, Indonesia.

Arts, B., 2012. Forests policy analysis and theory use: overview and trends. For. Policy Econ. 16, 7-13.

Baccini, A., Goetz, S., Walker, W., Laporte, N., Sun, M., Sulla-Menashe, D., et al., 2012 Estimated carbon dioxide emissions from tropical deforestation improved by carbondensity maps. Nat. Clim. Change 2 (3), 182-185.

Baumgartner, F.R., Jones, B.D., Wilkerson, J., 2011. Comparative studies of policy dynamics. Comp. Political Stud. 44, 947-972.

Brockhaus, M., Angelsen, A., 2012. Seeing REDD + through 4Is: a political economy framework. In: Angelsen, A., Brockhaus, M., Sunderlin, W.D., Verchot, L. (Eds.), Analysing REDD +: Challenges and Choices. Center for International Forestry Research, Bogor, Indonesia, pp. 15-30.

Brockhaus, M., Di Gregorio, M., 2014. National REDD + policy networks: from cooperation to conflict. Ecol. Soc. 19 (4), 14.

Brockhaus, M., Di Gregorio, M., Carmenta, R., 2014a. REDD + policy networks: exploring actors and power structures in an emerging policy domain. Ecol. Soc. 19 (4), 29.

Brockhaus, M., Di Gregorio, M., Mardiah, S., 2014b. Governing the design of national REDD +: an analysis of the power of agency. For. Policy Econ. 49, 23-33.

Brockhaus, M., Korhonen-Kurki, M.K., Sehring, J., Di Gregorio, M., Assembe-Mvondo, S., Babon, A., Bekele, M., Gebara, M.F., Dil Bahadur, D., Kambire, H., et al., 2016. REDD + , transformational change and the promise of performance-based payments: a qualitative comparative analysis. Clim. Policy. http://dx.doi.org/10.1080/ 14693062.2016.1169392.

Brown, K., O’Neill, S., Fabricius, C., 2013. Social Science Understandings of Transformation. In World Social Science Report 2013: Changing Globa Environments Paris. OECD Publishing and UNESCO Publishingpp. 100-107.

Corbera, E., Schroeder, H., 2011. Governing and implementing REDD +. Environ. Sci. Policy 14, 89-99.

Creswell, J., Plano Clark, V., 2007. Designing and Conducting Mixed Method Research. Sage Publications.

Cronin, T., Santoso, L., Di Gregorio, M., Brockhaus, M., Mardiah, S., Muharrom, E., 2016. Moving consensus and managing expectations: media and REDD + in Indonesia Clim. Change 137, 57. http://dx.doi.org/10.1007/s10584-015-1563-3.

Denscombe, M., 2008. Communities of practice. a research paradigm for the mixed methods approach. J. Mixed Methods Res. 2 (3), 270-283.

Di Gregorio, M., Nurrochmat, D.R., Paavola, J., Sari, I.M., Fatorelli, L., Pramova, E., Locatelli, B., Brockhaus, M., Kusumadewi, S.D., 2017. Climate policy integration in the land use sector: mitigation, adaptation and sustainable development linkages. Environ. Sci. Policy 67, 35-43. http://dx.doi.org/10.1016/j.envsci.2016.11.004.

Downe-Wamboldt, B., 1992. Content analysis: method, applications, and issues. Health Care Women Int. 13 (3), 313-321.

FCP, 2009. Indonesia R-PP. Available from:. www.forestcarbonpartnership.org.

Friedlingstein, P., Houghton, R., Marland, G., Hackler, J., Boden, T., Conway, T., et al., 2010. Update on CO2 emissions. Nat. Geosci. 3 (12), 811-812.

GCF Task Force, 2014. Central Kalimantan Governor Teras Narang Announces Rio Branco Declaration at UN Climate Summit. GCF Task Force. (Accessed 7 December 2016. http://www.gcftaskforce.org/news/article:2014-q3-un_climate_summit).

Grin, J., 2006. Reflexive modernization as a governance issue: or designing and shaping restructuration. In: Voss, J.P., Bauknecht, D., Kemp, R. (Eds.), Reflexive Governance for Sustainable Development. Edward Elgar, Cheltenham,United Kingdom, pp. $57-81$.

Grindle, M.S., 1999. In Quest of the Political: the Political Economy of Development Policy Making. CID Working Paper No. 17. Center for International Development at Harvard University Cambridge, MA, USA.

Gupta, J., 2012. Glocal forest and REDD + governance: win-win or lose-lose? Curr. Opin. Environ. Sustain. 4, 620-627.

Hajek, F., Ventresca, M., Scriven, J., Castro, A., 2011. Regime-building for REDD + : evidence from a cluster of local initiatives in south-eastern Peru. Environ. Sci. Policy 14, 201-2015.

Hall, P.A., 1997. 1997 The role of interests, institutions and ideas in the comparative political economy of the industrialized nations. In: Lichbach, M.I., Zuckerman, A.S. (Eds.), Comparative Politics: Rationality, Culture, and Structure. Cambridge University Press, Cambridge, UK, pp. 179-207.

Hoffmann, M., 2011. Climate Governance at the Crossroads: Experimenting with a Global Response After Kyoto. Oxford University Press, Oxford Unit ed Kingdom.

Holling, C.S., 1978. Adaptive Environmental Assessment and Management. John Wiley and Sons, Chichester, UK.
Indonesian REDD + Task Force, 2012. REDD + National Strategy. Jakarta, Indonesia.

Indrarto, G.B., Murharjanti, P., Khatarina, J., Pulungan, I., Ivalerina, F., Rahman, J., Prana, M.N., Resosudarmo, I.A.P., Muharrom, E., 2012. The Context of REDD + in Indonesia: Drivers, Agents and Institutions. Working Paper 92. Center for International Forestry Research, Bogor, Indonesia.

Kiema, A., 2014. How are the drivers of deforestation and forest degradation addressed in the national REDD + policy documents of Indonesia and Vietnam? Master's thesis. Faculty of Agriculture and Forestry. University of Helsinki.

Korhonen-Kurki, K., Brockhaus, M., Duchelle, A., Atmadja, S., Pham, T.T., Schofield, L., 2013. Multiple levels and multiple challenges for measurement, reporting and verification of REDD +. Int. J. Commons 7 (2), 344-366.

Korhonen-Kurki, K., Sehring, J., Brockhaus, M., Di Gregorio, M., 2014. Enabling factors for establishing REDD + in a context of weak governance: a qualitative comparative analysis. Clim. Policy 14 (2), 167-186.

Korhonen-Kurki, K., Brockhaus, M., Maharani, C., Dwistario, B., Babon, A., Bushley, B., Gebara, M.F., Kengoum, F., Molieno, M., Pham, T.T., et al., 2015. Coordination and cross-sectoral integration in REDD + : experiences from seven countries. Clim. Dev. 8 (5), 458-471. http://dx.doi.org/10.1080/17565529.2015.1050979.

Laumann, E., Knoke, D., 1987. The Organizational State: Social Choice in National Policy Domains. Univ of Wisconsin press (539p).

Luttrell, C., Resosudarmo, I.A., Muharrom, E., Brockhaus, M., Seymour, F., 2014. The political context of REDD + in Indonesia: constituencies for change. Environ. Sci. Policy 35, 67-675.

Maxwell, J., 1992. Understanding and validity in qualitative research. Harv. Educ. Rev. 62 (3), 279-301.

Mbatu, R., 2016. REDD + research: reviewing the literature, limitations and ways forward. For. Policy Econ. 73, 140-152.

Murdiyarso, D., Dewi, S., Lawrence, D., Seymour, F., 2011. Indonesia's Forest Moratorium: A Stepping Stone to Better Forest Governance? Working Paper 76. Center for International Forestry Research, Bogor, Indonesia.

Ostrom, E., 2011. Background on the institutional analysis and development framework. Policy Stud. J. 39 (1), 7-27.

Peskett, L., Schreckenberg, K., Brown, J., 2011. Institutional approaches for carbon financing in the forest sector: learning lessons for REDD + from forest carbon projects in Uganda. Environ. Sci. Policy 14, 216-229.

Pierson, P., 1993. Review: when effect becomes cause: policy feedback and political change reviewed work(s). World Politics 45 (4), 595-628.

Reinecke, S., Pistorius, T., Pregernig, M., 2014. UNFCCC and the REDD + partnership from a networked governance perspective. Environ. Sci. Policy 53, 30-39.

Sabatier, P.A., 2007. Theories of the Policy Process. Westview Press 344 p.

Salvini, G., Herold, M., De Sy, V., Kissinger, G., Brockhaus, M., Skutsch, M., 2014. How countries link REDD + interventions to drivers in their readiness plans: implications for monitoring systems. Environ. Res. Lett. 9 (7), 074004.

Scharpf, F., 2000. Institutions in comparative policy research. Comp. Political Stud. 33, $762-790$.

Scoones, I., Leach, M., Newell, P., 2015. The politics of green transformations. In The Politics of Green Transformations: Pathways to Sustainability. Earthscan, Routledge, London, United Kingdom, pp. 1-24.

Seymour, F., 2012. Interview with Frances Seymour, CIFOR: The Letter of Intent Prompted a Tectonic Shift in the Dialogue About Forests. REDD-Monitor. 13 April 2012. (Accessed 7 December 2016. http://www.redd-monitor.org/2012/04/13/ interview-with-frances-seymour-cifor-the-letter-of-intent-prompted-a-tectonic-shiftin-the-dialogue-about-forests/).

Sunderlin, W.D., Ekaputri, A.D., Sills, E.O., Duchelle, A.E., Kweka, D., Diprose, R. Doggart, N., Ball, S., Lima, R., Enright, A., et al., 2014. The Challenge of Establishing REDD + on the Ground: Insights from 23 Subnational Initiatives in Six Countries. Occasional Paper 104. Center for International Forestry Research, Bogor, Indonesia.

Van den Bosch, S., 2010. Transition Experiments: Exploring Societal Changes Towards Sustainability. Erasmus Universiteit Rotterdam, Rotterdam.

Walters, C.J., 1986. Adaptive Management of Renewable Resources. Macmillan, New York.

Westley, F., Olsson, P., Folke, C., Homer-Dixon, T., Vredenburg, H., Loorbach, D., Thompson, J., Nilsson, M., Lambin, E., Sendzimir, J., et al., 2011. Tipping toward sustainability: emerging pathways of transformation. AMBIO 40, 762-780.

Zeitlin, J., Pochet, P., Magnusson, L. (Eds.), 2005. The Open Method of Co-ordination in Action: The European Employment and Social Inclusion Strategies. PIE-Peter Lang, Bruxelles, Belgium; New York, United States. 